\title{
H2BU1 Gene
}

National Cancer Institute

\section{Source}

National Cancer Institute. H2BU1 Gene. NCI Thesaurus. Code C162985.

This gene plays a role in organization of chromatin-containing structures. 